\title{
The Importance of Genetic Diversity to Manage Abiotic Stress
}

\author{
Geraldo Magela de Almeida Cançado \\ Plant Biotechnology Laboratory, \\ Agricultural Research Agency of Minas Gerais (EPAMIG), \\ Caldas, $M G$, \\ Brazil
}

\section{Introduction}

Before the first half of Twentieth Century the biggest concern of the agricultural technology was the environmental adaptation instead of the development of plant varieties and livestock breeds with improved resistance or tolerance to biotic and abiotic stresses. Consequently, after decades of human intervention, the agriculture shift from a low impact activity to became a threat for environmental conservation. Besides that, over the years this model of "Green Revolution" proven to be ineffective in increase the yield continuously, since the genetic source of variability used in breeding programs became narrow and limited.

Afterwards, breeders began to change their strategies for developing new plant varieties and animal stocks. They started to realize and reflect on the value contained in the biodiversity and the genetic treasure available in landraces, exotic and wild species that evolved with the goal of be more adapted to their environment. Nowadays, researchers all around world are working hard to collect and preserve plant and animal samples for germplasm conservation because most of the wild life remains in continuous risk of extinction at natural environments. The main prompters of it are the agricultural activity itself, the rising land occupation by people and the heavy and growing industrial activity.

With the advance and deployment of new technologies, mainly in the field of the modern biotechnology, a new frontier was opened to the development and improvement of plants and animals. Nowadays is increasing the adoption of commercial transgenic organisms by farms and breeders. For some species as maize, cotton and soybean, most of the world production is already transgenic and the expectation is this kind of technology is going to be adopted for many of the species regularly used by man and replace the conventional crops. With the development of transgenic organisms, the insuperable sexual barriers considered before as a problem to hybridize different species are not longer a concern for plant and animal breeders. Now, this new technology allowed us the use of the whole gene pool available in the nature to improve plant and animal genotypes.

The natural environmental in many occasions can be hostile to living organisms. For species that not evolved to a specific and restricted condition, the chances to stay alive without human intervention are very small. Unfortunately, most of the cultivated species are not properly adapted to handle itself against several kinds of stress commonly found during its 
cultivation. The most restrictive factors faced by agriculture are the drought stress, attack of pests and diseases, poor soil fertility, soil salinity, excessive heat and cold, flooding, soil acidity and aluminum toxicity among many other types of stresses. Several wild species get used to these stresses because they are exposed to them for thousands of years, evolving to be low or even unaffected by them.

On centers of genetic diversity the chances to finding wild variants of species with traits of rusticity and resistance are greater than in any other place of Earth. The accurate knowledge, characterization and conservation of these variants in its diversity centers are crucial steps for the success of breeding programs whose aim nowadays is mainly focused in adaptability and improvement for marginal environments.

Besides that, the new tools of the modern biotechnology such as whole genome sequencing and large scale transcriptomes (microarrays) make the identification of genes involved with valuable traits easier and faster. A new perspective is emerging for the knowledge and use of biodiversity and the most incredible aspect of this new scientific field is the opportunity to rescue resistance genes from other living sources if it is not available in the target germplasm. Wild species and exotic relatives of crop plants as well as landraces contain valuable genes that are of immense genetic value in crop improvement programs. However, several species and variants of living beings are vanished from the Earth surface at daily basis in a rate never seen before. Nowadays the genetic diversity conservation is the biggest concern of humankind due its essential role in agriculture, medicine, industry and forestry and today it is a priority issue in many government's agenda. The dramatic fact is the gene pool available in wild species remains poorly known and unexplored in its numerous opportunities. Therefore, the main challenge is to preserve most of this richness for next generations.

\section{Population growth and genetic diversity}

The term abiotic stress was first used to describe the negative impacts of non-living factors on organisms in a given environment. In recent decades the use of this term has become constant and its effects are considered more and more concerning due the intense human activity as a result of the rapid world population growth (Fig. 1).

However, due to increasing global awareness and the prompt actions of governments in few countries, nowadays the rate of population growth in the world is a decreasing slope. In 2009 this growth rate was $1.2 \%$ while in 40 years ago it was $2.1 \%$ (Fig. 2). But the situation still worrying and it is far from the ideal. Many other countries must join these actions to ensure a sustainable world and decrease the pressure over the natural resources.

Many developing countries keep up with the rate of growth at a very accelerate pace. Thus, the prediction for population growth is worrisome. With the current rates, the predictions indicate that world population will be over 10 billion people around the year of 2100 (Fig. 3) increasing the negative effects on natural resources and changing the earth's climatic balance. The deleterious effects of this massive population growth can be already observed in the environment.

The recent and rapid increase in human population overload the need for food production. The "Industrial Revolution" that occurred from the $18^{\text {th }}$ to the $19^{\text {th }}$ centuries, also revolutionized food production in 1960s changing from traditional farmsteads that grew a variety of crops on smaller scale to the new industrial farms focused on growing massive amounts of a single product. This agricultural revolution became known as "Green Revolution". 
Consequently, the lands needed for food production moved from small farms to huge and continuous fields that enormously increased the demand for natural resources like soil and water. Thus, to make room for this new agricultural industry the destruction of natural environments has increased considerably since 1960.

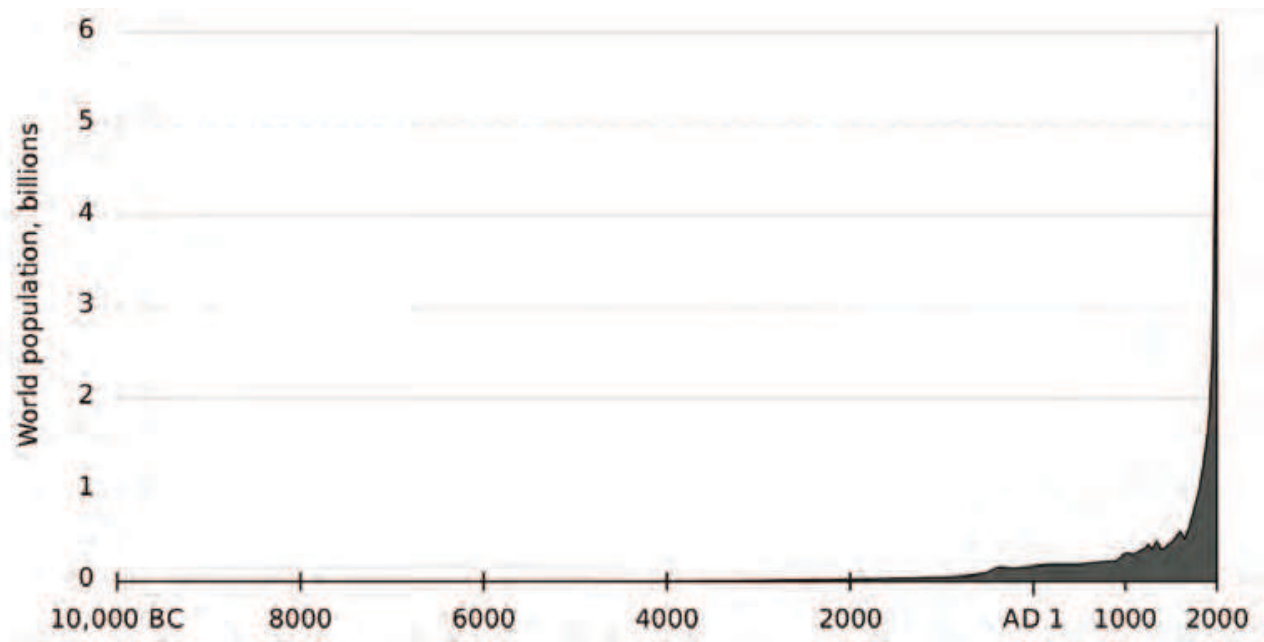

Fig. 1. World population curve from 10,000 BC to 2000 AD.



Fig. 2. World population growth rate. Percentage change of resident population compared to previous year. Data source: World Bank Development Indicators (April 26, 2011).

However, while the current agriculture is carried out in large areas increasing the natural resource demands, in the last 50 years they were not the only villain. Population growth and migration to urban centers have exacerbated the impact of cities on the environment. In 2007 for the first time in human history, the earth's population was more urban than rural, according to scientists from North Carolina State University and the University of Georgia 
(DALLAS, May 25, 2007, http://www.sciencedaily.com/releases/2007/05/070525 000642.htm).

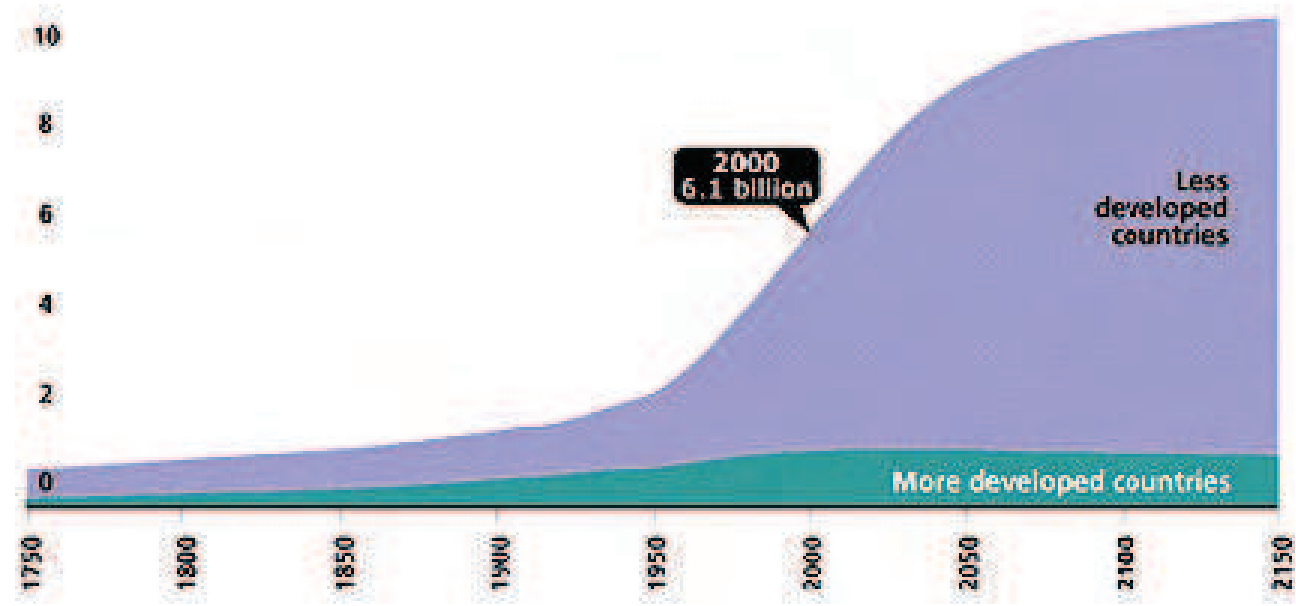

Fig. 3. World population growth (in billions) from 1750 to 2150. Data source: United Nations, World Populations Prospects, The 1998 Revision; and estimates by Population Reference Bureau.

In 1950 cities as São Paulo in Brazil, Mexico City in Mexico and Bombay in India, had population of 2.33, 2.88 e 2.86 millions of habitants, respectively. In 2010 these same cities recorded population numbers of 20.26, 19.46 and 20.04 millions, representing a stunning growth of $869.5 \%, 675.7 \%$ and $700.7 \%$, respectively, in a short period of six decades (United Nations, Department of Economic and Social Affairs, World Urbanization Prospects: The 2009 Revision, http:/ / esa.un.org/unpd/wup/ index.htm).

One of the main reasons for this dramatic urban growth is the migration from rural lands to urban areas. Small and traditional farms are left behind because they have become uncompetitive and non-profit when compared to the current agribusiness industry.

There are many kinds of abiotic stress and they can be originated from natural sources or trigged by human activity. The most common examples are extreme temperatures, drought, flood, high winds, soil salinity, mineral deficiency and toxicity, soil and water poisoning as well as other natural disasters such as tornadoes, wildfires, volcanic activities and earthquakes. All of them may affect plant growth and reproduction at different severity levels.

According to recent data from research carried out by several scientific teams worldwide, agriculture and livestock have played a considerable role in the environmental changing, including global warming due greenhouse gas emission, land degradation and desertification, air and water pollution and intense loss of biodiversity (FAO, http://www.fao.org/ag/magazine/0612sp1.htm).

Deforestation, desertification, use of fossil fuels are examples of anthropogenic sources of devastation that aggravates abiotic stress effects. The agriculture production, massive land use and biomass burning together contribute to $22.5 \%$ of the green house gas emissions, $46.6 \%$ of methane production and $88 \%$ of the nitrous oxide (Fig. 4 ). 




Fig. 4. Annual greenhouse gas emissions by sector. Data source: Kedar Karki. Effect of Climate change in agriculture and livestock production

(http:// pt.scribd.com/doc/3323459/Effect-of-Climate-change-in-agriculture-and-ivestockproduction).

The main victims of the increasing abiotic stress are the fauna and flora closely followed by the poor populations living in marginal areas. Although in a natural context all living organisms are frequently exposed to any kind of abiotic stress during their life, the natural evolution plays a fundamental role to adapt and adjust these orgarnisms to adverse conditions in a process that evolve in a continuous and slow way. However, today what we observed is the majority of wild species are not able to overcome as quickly as necessary to adapt to abrupt changes that are occurring in the environment. Therefore, scientists are estimating that the number of species extinction is happening in a rate 1000 folds faster than would occur if the anthropic interference was not so intense.

The society and many Governments begun to realize that the time for change is right now. Agriculture has undergone a huge shift from the paradigm introduced by the "Green Revolution" which advocated the radical environment intervention to make it friendly to agriculture and now it is beginning to be replaced by the concept of sustainable agriculture where crops and livestock must be designed by breeders having as goal the better adaptation to environment, and consequently, a better performance against biotic and abiotic stresses.

The major challenge, however, results from the complex nature of abiotic stress-tolerance traits and the difficulty in dissecting them into manageable genetic components feasible to be modified by molecular approaches. In crop breeding, advances in molecular biology and genomics have had a large impact on the speed of identification and characterization of genes and genetic regions associated with quantitative and qualitative traits. Markerassisted selection through the use of high-throughput marker systems are currently being 
used extensively in breeding programs to improve selection efficiency, accuracy and to direct focus towards traits of great importance for adaptation (Sutton, 2009).

Association between gene activity and response to abiotic stress is the major challenge involving functional genomics research and plant and animal breeding. New tools and approaches as genetic modification, gene knockout, RNA interference, genomics, proteomics, metabolomics and metagenomics have allowed new insights in this field and many advances in the role of genetics controlling complex traits such as those involved with response to abiotic stress.

The genetic variability acumulated in various plant species and involved with increase of production and adaptation to less favorable environments is being used by humankind since beginning of agriculture by selection of seeds collected from the best genotypes. Altough in the "Green Revolution" the main focus of the genetic improvement has been converged to large and uniform productions, currently features such as disease resistance, nutritional quality and abiotic stress tolerance have assumed a prominent space in the attention of modern breeding programs.

Moreover, genetic engineering has proven to be a strong ally to the conventional plant breeding, transposing the sexual barriers among species and allowing the expansion of search for desirable agronomic traits virtually to all living beings. It also make the breeding process less random since specific traits might be handled without fear of genetic dragging (i.e. the inheritance of negative traits genetically linked to desirable traits).

Below we will detail some of the main abiotic stress and how molecular biology and genetic engineering can be used to alter cellular metabolism towards the genetic improvement to abiotic stress tolerance.

\section{Types of abiotic stress}

\subsection{Metal toxicity}

The compartmentalization of toxic ions in the vacuole is a strategy widely used by plants when exposed to various types of stress. Thus the cytoplasmic sites are protected from possible toxic effects of ions such as $\mathrm{Al}, \mathrm{Mn}, \mathrm{Zn}$ and $\mathrm{Cd}$. Tobacco plants expressing the gene CAX2 from Arabidopsis, which encodes an exchanger in $\left[\mathrm{Ca}^{2+}\right] /\left[\mathrm{H}^{+}\right]$, showed higher tolerance to $\mathrm{Mn}$, possibly due to the fact that this protein also acts in transport of $\mathrm{Mn}^{2+}$ and $\mathrm{Cd}^{2+}$ to the vacuole (Hirschi et al., 2000). Arabidopsis plants overexpressing ZAT gene showed no sign of stress when exposed to $0.2 \mathrm{mM}$ zinc, concentrations that cause chlorosis and inhibits the growth of untransformed plants (Zaal et al., 1999). The ZAT gene encodes a probable carrier, which transfers $\mathrm{Zn}^{2+}$ from the cytoplasm to the vacuole.

The toxicity of $\mathrm{Al}^{3+}$ ion is an important factor limiting plant growth in acid soils, such as savannahs in Africa and cerrado in Brazil. Many plant species exude organic acids in response to toxic levels of Al. De la Fuente et al. (1997), altered the balance of organic acids in tobacco plants and papaya, through overexpression of a gene that encodes a citrate synthase of Pseudomonas aeruginosa. This disturbance in metabolism caused an increase in citrate exudation by root cells. By assessing the growth of transgenic plants in a solution containing toxic levels of $\mathrm{Al}$, the authors observed a significantly better performance in these plants than that observed in wild plants. This is probably due to the chelating action of citrate over the ions of $\mathrm{Al}^{3+}$, preventing the toxic effects of this ion.

Cançado et al. (2008) working with root tips of two contrasting Al tolerance maize lines (Fig. 5) identified several genes whose responses were altered by the stress trigged by $\mathrm{Al}$. 
The toxicity promoted by this metal is one of the major limiting factors to plant growth in acid soils. The most dramatic symptom of Al toxicity is the inhibition of root growth and consequently, the water uptake and mineral nutrition in plants affected by $\mathrm{Al}$ is completely unbalanced. Cançado et al. (2008) used an approach where more than two thousands genes were evaluated simultaneously. Many genes showed up-regulated expression while another showed down-regulated expression when the maize plants were exposed to Al stress.

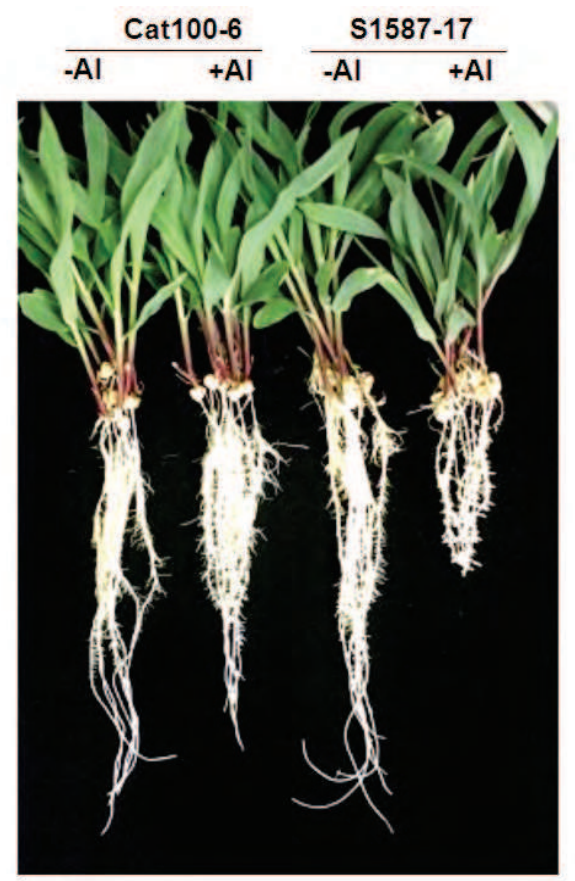

Fig. 5. Root growth of two aluminum-contrasting maize genotypes, Cat 100-6 aluminum tolerant and S1587-17 aluminum sensitive, after five days in nutrient solution with aluminum and without aluminum (control). Source: Cançado et al. (2008).

As example of up-regulated the autors found genes encoding proteins previously identified in several other works as induced by aluminum stress, such as phenyl ammonia-lyase, chitinase, Bowman-Birk proteinase inhibitor, and wali7. Most of these genes were upregulated only in the tolerant maize genotype, strongly indicating a putative role of these genes in the trait of aluminum tolerance in this genotype. The use of maize transgenic plants overexpressing or silencing aluminum-stress responsive genes in the root tips may be a useful tool to clarify the role of these genes in the aluminum tolerance.

Cançado et al. (2005) studying a gluthatione $S$ tranferase (GST) gene in the same maize lines cited above also observed that this gene showed nucleotide differences between both genotypes that reflected in differences in the amino acid composition of the proteins encoded by theses genes in each maize line. Modeling of the tertiary structure of the GSTs in each line evidenced that there were different not only in composition but as well in the spatial folding of the catalytic site. 


\subsection{Salt stress}

Salt stress causes large drops in productivity due to excess $\mathrm{Na}^{+}$. The principal strategies employed to minimize the effects of toxic salt is the uptake blocking of $\mathrm{Na}{ }^{+}$or sequestration of these ions in the intracellular vacuole in addition to the synthesis of molecules osmoprotectant such as sucrose, proline, betaine and trehalose that allow osmotic adjustment, stabilizing some macromolecules and maintaining the integrity of the membrane (Garcia et al., 1997).

Apse et al. (1999), scanning the genome project data from Arabidopsis thaliana, found the AtNHX1 gene, homologous to yeast Nhx1 gene, which encodes a protein that acts transporting sodium ions into the vacuole. The authors observed that overexpressing AtNHX1 gene in A. thaliana the exchange rate between $\mathrm{Na}^{+}$and $\mathrm{H}^{+}$in the vacuoles was much greater than that observed in wild plants. Associated with that, the authors verified that the transgenic plants showed normal development when kept in a nutrient solution containing $200 \mathrm{mM} \mathrm{NaCl}$, while wild plants had their growth strongly inhibited, with reduced leaf size and chlorosis.

In another successful example, Prasad et al. (2000) transformed Brassica juncea with the codA gene from Arthrobacter globiformis, which encodes the enzyme choline oxidase involved in the synthesis of glycine-betaine, an osmoprotectant. The transgenic plants when exposed to toxic concentrations of $\mathrm{NaCl}$, showed better performance than the wild plants.

One consequence of various types of stress, such as saline, is the production of reactive oxygen species, which interact with various cellular components. Overexpression of enzymes involved in detoxification of compounds generated by oxidative stress has been employed to obtain plants with high performance against various types of stress. Roxas et al. (1997) produced tobacco plants overexpressing genes that encode a glutathione S-transferase and glutathione peroxidase. These plants showed some performance improvement in environments containing toxic concentrations of salts compared to normal environments.

\subsection{Temperature}

High temperatures affect the photosynthetic capacity of plants, with clear effects on agricultural yield. There are several indications that the average temperatures of Earth surface is increasing, perhaps as a result of the greenhouse effect. Thus, the production of plants with improved performance against high temperatures is a research field that arouses great attention worldwide.

Recently, Murakami et al. (2000) modified the composition of fatty acids in thylakoid membranes of chloroplasts from tobacco plants. Expressing the anti sense gene that encodes a desaturase of omega-3 there was a decrease in the proportion of unsaturated lipids, increasing the thylakoid membrane fluidity. The transgenic plants showed better performance when exposed to $36^{\circ} \mathrm{C}$ and $40{ }^{\circ} \mathrm{C}$ while the rate of photosynthesis was greater than that observed in wild plants.

The manipulation of the synthesis of glycine-betaine using the gene code of Arthrobacter globiformis in Arabidopsis plants also produced encouraging results regarding the tolerance to heat and cold. Alia et al. (1998) obtained plants with high levels of choline oxidase, which induced the accumulation of glycine-betaine. These plants had higher heat tolerance during seed germination and early stages of seedling development. These same plants also showed increased tolerance to cold (Sakamoto et al., 2000). Thus, manipulation of osmoprotector levels is a strategy that can improve the performance of plants against various types of abiotic stresses. 
Similary to the example of the protection observed with respect to salt stress, the expression of genes encoding enzymes that combat oxidative stress also has beneficial effects on plants exposed to low temperatures. In maize plants, overexpression of a gene for superoxide dismutase in chloroplasts from tobacco increased the metabolism capacity of superoxide radical $\left(\mathrm{O}_{2}^{-}\right)$, which is toxic to cells (Van Breusegem et al., 1999). Thus there is an improvement in cold tolerance.

\subsection{Phosphorus deficiency}

Phosphorus deficiency is a major factor limiting agricultural productivity. To meet the needs of $\mathrm{P}$ it is necessary high investment in fertilizer application, which in turn leads risk of environmental pollution.

A response often observed in plants growing in $\mathrm{P}$ deprivation is the exudation of organic acids. López-Bucio et al. (2000) assessed the effects of P deficiency in transgenic plants with increased tolerance to $\mathrm{Al}$ (De la Fuente et al., 1997), which exsudated higher citrate levels due to overexpression of the gene citrate synthase. The transgenic plants when grown in alkaline soil with low $\mathrm{P}$ availability had larger leaf area and dry weights of fruits and they were taller than wild plants. This performance is associated with higher levels of $\mathrm{P}$ intracellular. Supposedly, citrate increases the availability of $\mathrm{P}$ by moving it into insoluble complexes.

Another alternative for expanding the ability to uptake phosphate is the overexpression of proteins that act transporting P to the interior of root cells. Mitsukawa et al. (1997) expressed the gene PHT1 of Arabidopsis in cell cultures of tobacco. When transferred to medium without $\mathrm{P}$ for 4 days, the transgenic cells showed increase of $42 \%$ in the fresh weight compared to control cells, probably due to increased ability to acquire P (up to 3 times higher than in control cells).

\section{The genomics as a tool for discovery of genes related to abiotic stress}

Recent technological advances of the apparatus of sequencing and bioinformatics have allowed the discovery of a huge number of genes in a very short time. Genes associated to agronomic traits of interest are being sequenced by genome projects like ESTs (expressed sequence tags). These projects identify expressed genes in different tissues and stages of plant development.

Togheter with the ability to discover new genes, the technology for simultaneous analysis of thousands of genes have also evolved, with the possibility of access the expression profile of a myriad genes by using cDNA arrays, consisting of cDNA clones neatly set on supports of glass or nylon. The microarrays are arrays of genes in high-density platform, usually set on glass holder (Schena et al., 1995) while the macroarrays have lower density of genes, normally spotted on nylon membranes (Dezprez et al., 1998). These DNA arrangements can be hybridized with different cDNA probes representing the messengers RNA of distinct populations of cells. By comparing the signals of each gene with the different probes it is possible to evaluate the expression pattern of thousands of genes simultaneously (Fig. 6).

The large scale technology for gene expression study allowed researchers assess which genes are activated by plants in response to various types of stress, as demonstrated in the response of Arabidopsis plants to a deficiency of nitrate (Wang et al., 2000). The authors evaluated 5524 genes and identified 40 induced genes, which encode transcription factors, enzymes of several metabolic pathways and proteins without known function. 
Nogueira et al. (2003) have studied the response of sugarcane to abiotic stresses, using nylon membranes containing clones of sugarcane ESTs. These membranes were hybridized with probes obtained by reverse transcription of total RNA from treated and control plants. The methodology allowed the identification of several genes up-regulated by low temperatures in sugarcane.

\section{Control cDNA (without $\mathrm{Al}^{3+}$ stress)}

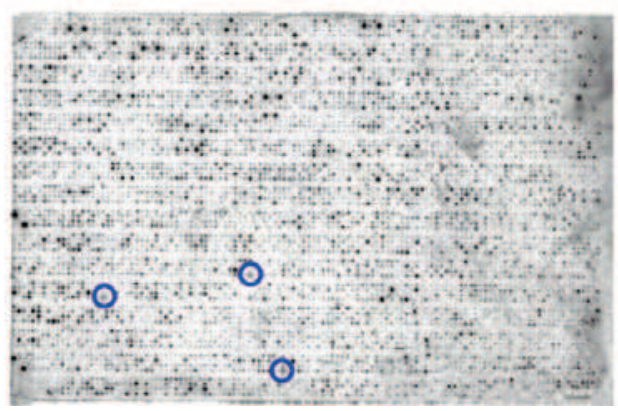

Treated CDNA (plus $\mathrm{Al}^{3+}$ stress)

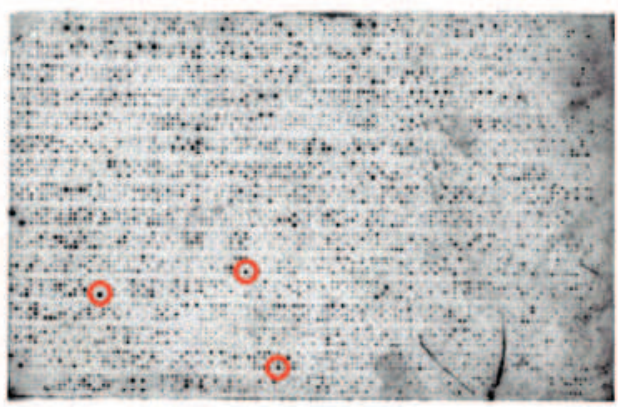

Fig. 6. Two filter arrays (macroarrays) hybridized with radioactive labelled probes (cDNA) obtained from two samples of maize root tips: one growing in a control treatment and another growing in presence of toxic aluminum. The circulated spots indicate cDNAs whose expression was up-regulated by aluminum stress (Cançado et al., 2008).

The technology of DNA arrays have an important contribution during the identification of new genes that may be employed for producing transgenic plants as well as molecular markers in classic breeding programs.

\section{Gene diversity and biodiversity}

Diversity is a fundamental foundation to promote sustainable and environmentally friendly agriculture and livestock. In this case the concept of diversity is wide and it goes from number of species used by mankind, through the large number of varieties and breeds within each specie and finally, reaching the genetic richness inside the genome of each organism.

Although the DNA molecule was already known as the molecule responsible to storage the genetic inheritance, until the late 80 s very little was known about the role of genes. With the fast technological progress observed in the biotechnological research since then, much was disclosure and new opportunities of improve the adaptation to abiotic stress began to emerge.

The vast concept of biodiversity can be defined as the conjunct of all existing living organisms, that inhabit the biosphere, with their taxonomic and ecological characteristics, their genetic variation, without considering the chemical and physical factors of the environment. Therefore, not only the differences between species but also the differences within the same species aggregates value to the biodiversity (Sandes \& DiBiasi, 2000; Varella et al., 1998). Thus, greater is the biological variation and the abundance of species in a given location, greater is going to be the biodiversity and vice versa.

In biodiversity there is an hierarchical relationship between the different levels, starting in the gene through the individual, then through species and so on into specie populations, 
ecosystems and finally reaching the most complex network level of interaction between living organisms with the surrounding environment.

Some predictions indicate that a number of different living organisms that inhabit the Earth diverge from 5 to 100 million, but until now has only identified around 1.7 millions (Wilson, 1999). This large variation in species number is due to the myriad of microorganisms, insects and fungi that colonize the most diverse places on Earth and which still remains unknown. Recently, a group of NASA researchers in the U.S. discovered a new specie of bacteria that use Arsenic in its DNA molecule instead of Phosphorus, breaking the paradigm that the DNA molecule has the same composition in all living beings (Wolfe-Simon et al., 2010). This fact illustrates how our knowledge about this subject still in its childhood. The awful truth is that we don't even know exactly how many species there are in flora and fauna of Earth. At general, the biodiversity is larger in tropical lands decreasing with the rising of latitude and altitude, being richer in places where rainfalls are more abundant and poorest in arid regions.

Since their evolutionary climb up to the present day of modern civilization, man has used as food only $1 \%$ of the nearly 300,000 known species of higher plants. At present, only $0.1 \%$ of existing species are used, with only 15 of them being responsible for about $90 \%$ of all food (Goodman, 1990). More than $60 \%$ of food production that reach consumers in all world are based on four main products: potatoes, rice, wheat and corn (Diniz \& Ferreira, 2000).

Conservation of genetic resources available in biodiversity, as well as the knowledge of genes role, is important not only for the nations that harbor this biodiversity but also for the humanity, because it can ensuring its maintenance and food security in the future. Genetic resources are invaluable because have an incalculable potential for use and application now and in the future generations, holding ecological, genetic, social, economic, scientific, educational, cultural, recreational and aesthetic value (Varella et al., 1998). However the complexity of their benefits is still little known and measured by mankind.

Anthropogenic interference on natural ecosystems is currently the main cause for the biodiversity reduction and poverty is one of the most destructive forces in tropical lands. According to Mendonça-Hagler (2001), the emergence and extinction of species are natural phenomena that occur on defined geologic ages. However, if the destruction of ecosystems and habitats continues at its current pace, considering that there are 100 millions of different species on Earth, currently it is estimated that at least ten thousands species go extinct every year (considering an extinction rate of $0.01 \%$ /year). This rate is higher or lower depending on location. In countries like the US, where much of the biodiversity has already been extinguished the rate today is lower, but in places like Malaysia and the Amazon basin, the rate may be much higher than in other places on Earth due the high abundance of threatened species that still have this kind of environmental as natural habitat. In fact, the lack of knowledge about species richness is so great that it is difficult to accurately measure the rate of species loss.

Considering mainly the agriculture, the big concern about biodiversity reduction is the loss of genetic diversity also known as "genetic erosion". Many commercially cultivated species have narrowed their genetic basis due to intense process of yield improvement that reduced the number of genotypes useful for breeding programs. Most of genetic variability in plants is preserved in wild relatives that still present in the centers of diversity. Nevertheless, most of these centers of diversity are being reduced or even vanished from nature, forcing researchers to preserve a small fraction of this genetic variability in germplasm collections 
maintained artificially. Wild relatives have always been useful for breeders, through the hybridization process using gene pools from native and exotic species and transfering them to cultivated species, improving for example, resistance to disease or pest attack.

With the biotechnology evolution and adoption by agriculture, today is possible to transfer specifically one gene involved with the characteristic of interest directly to the genome of a host organism, which for example can be a variety or hybrid of a commercial plant.

\section{Using biotechnology to alleviate abiotic stress in plants}

Unlike animals, plants are inherently immovable and consequently throughout its evolution they needed evolve intricate ways to response quickly and efficiently to effects of biotic and abiotic stress. The genetic code of each plant was assembled and refined by the environment surrounding to give the exact response to each stress in a very cordenate and efficient way. Of course, each location with its specific peculiarities prompeted the evolution process to promote the most appropriate combination of genes involved with the expression of the best traits, making plants able to handle with specific adversities of its environment.

Thus, the best chances to dealing with the harmful effects of abiotic stress are prospecting adequate genes available in genetic diversity of living beings. Since the dawn of agriculture, man has already improved the plant species, even if it was carried out in an unconscious way. However, the limitations imposed by reproductive barriers between species prevented breeders to exploit the potential of the gene pool available in nature and thus hindering the development of new varieties by preventing the use of genes most useful for dealing with rough conditions. For many centuries the solution was to modify the environment in an attempt to make it more suitable for growing plants. However, with the development of recombinant DNA technology about 40 years ago, a new perspective was created for plant breeding.

The first transgenic plants were created in the early 1980s by four groups working independently at Washington University and Monsanto Company both in St. Louis, Missouri; the Rijksuniversiteit in Ghent, Belgium; and the University of Wisconsin. On the same day in January 1983, the first three groups announced at a conference in Miami, Florida, that they had inserted bacterial genes into plants. The fourth group announced at a conference in Los Angeles, California, in April 1983 that they had inserted a plant gene from one species into another species.

The Washington University group, headed by Mary-Dell Chilton, had produced cells of Nicotiana plumbaginifolia, a close relative of ordinary tobacco, that were resistant to the antibiotic kanamycin (Bevan et al., 1983). Jeff Schell and Marc Van Montagu, working in Belgium, had produced tobacco plants that were resistant to kanamycin and to methotrexate, a drug used to treat cancer and rheumatoid arthritis (Herrera-Estrella al., 1983). Robert Fraley, Stephen Rogers, and Robert Horsch at Monsanto had produced petunia plants that were resistant to kanamycin (Fraley et al, 1983). The Wisconsin group, headed by John Kemp and Timothy Hall, had successfully inserted a bean gene into a sunflower plant.

From this point, the transgenic technology provides the tools to make even more distant "crosses" among plants. The use of this technology to improve resistance and tolerance to biotic and abiotic stress was quickly seen as an attractive target for commercial applications. The genetic engineering for developing stress tolerant plants, based on the introgression of genes previously identified as responsive to abiotic stress might assume the major role towards the development of improved plant cultivars. 
Plants can be genetically transformed to be tolerant to several kinds of stress such as salinity, drought, heat, flooding and metal toxicity. Most of these stress inductors promote the response of several genes in a very coordinate way, therefore the simultaneous or cumulative genetic transformation with multiple genes seen to be more suitable to this kind of stress. In some cases not only the gene assumes important role but also their promoters that allow the fine control of the expression level, the most adequate timing and targeting the correct tissue, making this technology work in a very precise way and promoting the optimal functionality of these introduced genes.

\section{Conclusions and perspectives}

The large number of reports clearly shows that manipulation of metabolic pathways using genetic engineering is a strategy that improves the performance of plants against abiotic stress. However, in most cases the impact of transgene does not confer high levels of tolerance.

There is a possibility to increase the tolerance through of the expressing simultaneously transgenes involved in several metabolic pathway. Alternatively, may be used transcription factors that regulate the expression of several defense genes at the same time, as described by Kasuga et al. (1999). These authors induced the expression of the transcription factor CBF1, which induced the expression of several genes normally activated in response to cold in Arabidopsis. The transgenic plants had higher tolerance not only at low temperatures, but also to drought and salinity. Accordingly, genomic technologies have a central role in the discovery of genes that regulate the intricate defense networks activated by plants in response to several types of environmental challenges.

With the improvement of plant genetic transformation technologies, certainly those genes previously evaluated mainly in tobacco and Arabidopsis will be also transferred to agronomic crops such as corn, wheat, soybeans and rice. Still, it is necessary to emphasize that only trials in field conditions will accurately assess the degree of protection offered by transgenes.

Finally, the joining of new molecular technologies and the experience and methods of classical geneticists will increase production and reduce costs, with an impact certainly stronger than those observed during the "Green Revolution".

Actually, this approach might be applied for almost every case of abiotic stress and even to biotic stress, helping to elucidate the genetic mechanisms behind the behavior difference observed in plants of the same specie when exposed to the same kind of stress. Indeed not only the genes but also the nucleotide sequences involved in the expression control such transcription factors, promoters, enhancers among many other ways of gene regulation are very important in these cases.

Evolutionary events such as gene duplication are very important to create the genetic buffer that allows plants to experience mutation events and create new versions of genes without risk of loss of functionally in vital metabolic pathways. Mobile genetic elements known as retrotransposons are a huge source of genetic variability and they are observed in most of the living organisms in a very variable number. In plants they played a very important role during the genome evolution and they are still important to keep this process going on. Recent discoveries about the mechanism of gene silencing ruled by RNA interference explains how plants can fight against viral infection and genetic disturbances promoted by uncontrolled gene expression, working as a very fine-tuning process inside the cell. 
Plants are unable to dislocate in its own environmental therefore they had evolve to solve abiotic and biotic stress with internal mechanisms of tolerance and resistance. Consequently, the gene must evolve to perform and adapt quickly to environmental changes.

\section{Acknowledgments}

The author would like to thank the financial support from Minas Gerais Research Foundation (FAPEMIG), São Paulo Research Foundation (FAPESP), Coordination for the Improvement of Higher Education Personnel (CAPES), Funding Agency of Studies and Projects (FINEP) and Brazilian Agricultural Research Corporation (EMBRAPA) during the development of some results presented in this chapter.

\section{References}

Alia, HH; Sakamoto, A \& Murata, N (1998) Enhancement of the tolerance of Arabidopsis to high temperatures by genetic engineering of the synthesis of glycinebetaine. Plant Journal 16:155-161

Apse, MP; Aharon, GS; Snedden, WA \& Blumwald, E (1999) Salt tolerance conferred by overexpression of a vacuolar $\mathrm{Na}^{+} / \mathrm{H}^{+}$antiport in Arabidopsis. Science 285:12561258.

Bevan, MW; Flavell, RB \& Chilton, MD (1983) A chimeric antibiotic resistance gene as a selectable marker for plant cell transformation. Nature 304:184-187

Cançado, GMA; Nogueira, FTS; Camargo, SR; Drummond, RD; Jorge, RA \& Menossi, M (2008) Gene expression profiling in maize roots under aluminum stress. Biologia Plantarum 52:475-485

Cançado, GMA; Rosa-Junior, VED; Fernandez, JH; Maron, LG; Jorge, RA \& Menossi, M (2005) Glutathione. S-transferase and aluminum toxicity in maize. Functional Plant Biology 32:1045-1055

De la Fuente, JM; Ramirez-Rodriguez, V; Cabrera-Ponce, JL \& Herrera-Estrella, L (1997) Aluminum tolerance in transgenic plants by alteration of citrate synthesis. Science 276:1566-1568

Desprez, T; Amselem, J; Caboche, M \& Hofte, H (1998) Differential gene expression in Arabidopsis monitored using cDNA arrays. Plant Journal 14:643-652

Diniz, MF \& Ferreira, LT (2000) Bancos genéticos de plantas, animais e microganismos. Biotecnologia, Ciência \& Desenvolvimento 2(13):34-38

Fraley, RT; Rogers, SG; Horsch, RB; Sanders, PR; Flick, JS; Adams, SP; Bittner, ML; Brand, LA; Fink, CL; Fry, JS; Galluppi, GR; Goldberg, SB; Hoffmann, NL \& Woo, SC (1983) Expression of bacterial genes in plant cells. Proceedings of the National Academy of Sciences USA 80:4803-4807

Garcia, AB; Engler, JDA; Lyer, S; Gerats, T; Van Montagu, M \& Caplan, AB (1997) Effect of osmoprotectants upon $\mathrm{NaCl}$ stress in rice. Plant Physiology 115:59-169

Goodman, MM (1990) Genetic and germplasm stocks worth conserving. Journal of Heredity 81:11-16

Herrera-Estrella, L; Depicker, A; Van Montagu, M \& Schell, J (1983) Expression of chimeric genes transfered into plant cells using a Ti-plasmid-derived vector. Nature 303:209-213. 
Hirschi, KD; Korenkov, VD; Wilganowski, NL \& Wagner, GJ (2000) Expression of Arabidopsis CAX2 in tobacco. Altered metal accumulation and increased manganese tolerance. Plant Physoiology 124:125-134.

Kasuga, M; Liu, Q; Miura, S; Yamaguchi-Shinozaki, K \& Shinozaki K (1999) Improving plant drought, salt, and freezing tolerance by gene transfer of a single stress-inducible transcription factor. Nature Biotechnology 17:287-291

López-Bucio, J; de la Vega, M; Guevara-García, A \& Herrera-Estrella, L (2000) Enhanced phosphorus uptake in transgenic tobacco plants that overproduce citrate. Nature Biotecnology 18:450-453

Mendonça-Hagler, LCS (2001) Biodiversidade e biossegurança. Biotecnologia, Ciência E Desenvolvimento 3(18):16-22

Mitsukawa, N; Okumura, S; Shirano, Y; Sato, S; Kato, T; Harashima, S \& Shibatga, D (1997) Overexpressing of an Arabidopsis thaliana high-affinity phosphate transporter gene in tobacco cultured cells enhances cell growth under phosphate-limited conditions. Proceedings of the National Academy of Sciences USA 94:7098-7102

Murakami,Y; Tsuyama, M; Kobayashi, Y; Kodama, H \& Iba, K (2000) Trienoic fatty acids and plant tolerance of high temperature. Science 287:476-479

Nogueira, FTS; Rosa-Júnior, VE; Menossi, M; Ulian, EC \& Arruda, P (2003) RNA expression profiles and data mining of sugarcane response to low temperature. Plant Physiology 132:1811-1824

Prasad, KVSK; Sharmila, P; Kumar, PA \& Saradhi, PP (2000) Transformation of Brassica juncea (L.) Czern with bacterial codA gene enhances its tolerance to salt stress. Molecular Breeding 6:489-499

Roxas, VP; Smith, RK; Allen, ERJr \& Allen, RD (1997) Overexpression of glutathione Stransferase/glutathione peroxidase enhances the growth of transgenic tobacco seedlings during stress. Nature Biotechnology 15:988-991

Sakamoto, A; Valverde, R; Alia; Chen, THH \& Murata N (2000) Transformation of Arabidopsis with the codA gene for choline oxidase enhances freezing tolerance of plants. Plant Journal 22:449-453

Sandes, ARR \& DiBiasi, G (2000) Biodiversidade e diversidade químico e genética. Biotecnologia, Ciência E Desenvolvimento 2(13):28-32

Schena, M; Shalon, D; Davis, RW \& Brown, PO (1995) Quantitative monitoring of gene expression patterns with a complementary-DNA microarray. Science 270:467-470

Sutton, TJ (2009) Functional genomics and abiotic-stress tolerance in cereals In: Proceedings of the 21st Annual conference of the National Agricultural Biotechnology Council, Adapting Agriculture to Climate Change - NABC 21: pp.57-64. Publisher CSIRO, ISBN 9780643095953

Van Breusegem, F; Slooten, L; Stassart, JM; Botterman, J; Moens, T; Van Montagu M \& Inze, D (1999) Effects of overproduction of tobacco MnSOD in maize chloroplasts on foliar tolerance to cold and oxidative stress. Journal of Experimental Botany 50:71-78

Varella, MD; Fontes, E \& Rocha, FG (1998) Biossegurança e biodiversidade: contexto científico regulamentar. Belo Horizonte: Editora Del Rey, 304p.

Wang, RC; Guegler, K; LaBrie, ST \& Crawford, NM (2000) Genomic analysis of a nutrient response in Arabidopsis reveals diverse expression patterns and novel metabolic and potential regulatory genes induced by nitrate. Plant Cell 12:1491-1509

Wilson, EO (1999) The diversity of life. New York: W.W. Norton \& Company, 424p. 
Wolfe-Simon, F; Blum, JS; Kulp, TR; Gordon, GW; Hoeft, SE; Pett-Ridge, J; Stolz, JF; Webb, SM; Weber, PK; Davies, PCW; Anbar, AD \& Oremland, RS (2010) A bacterium that can grow by using arsenic instead of phosphorus. Sciencexpress, DOI: 10.1126/Science.1197258

Zaal, BJ; Neuteboom, LW; Pinas, JE; Chardonnens, AN; Schat, H; Verkleij, JAC \& Hooykaas, PJJ (1999) Overexpression of a novel Arabidopsis gene related to putative zinctransporter genes from animals can lead to enhanced zinc resistance and accumulation. Plant Physiology 119:1047-1056 


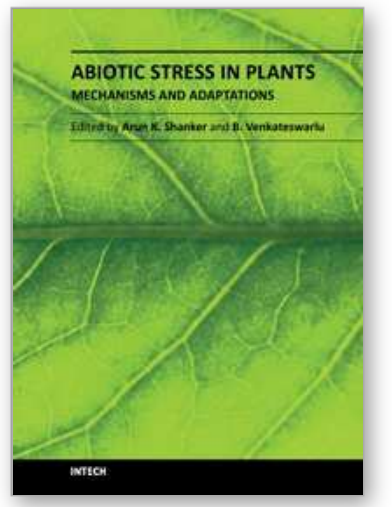

\author{
Abiotic Stress in Plants - Mechanisms and Adaptations \\ Edited by Prof. Arun Shanker
}

ISBN 978-953-307-394-1

Hard cover, 428 pages

Publisher InTech

Published online 22, September, 2011

Published in print edition September, 2011

World population is growing at an alarming rate and is anticipated to reach about six billion by the end of year 2050. On the other hand, agricultural productivity is not increasing at a required rate to keep up with the food demand. The reasons for this are water shortages, depleting soil fertility and mainly various abiotic stresses. The fast pace at which developments and novel findings that are recently taking place in the cutting edge areas of molecular biology and basic genetics, have reinforced and augmented the efficiency of science outputs in dealing with plant abiotic stresses. In depth understanding of the stresses and their effects on plants is of paramount importance to evolve effective strategies to counter them. This book is broadly dived into sections on the stresses, their mechanisms and tolerance, genetics and adaptation, and focuses on the mechanic aspects in addition to touching some adaptation features. The chief objective of the book hence is to deliver state of the art information for comprehending the nature of abiotic stress in plants. We attempted here to present a judicious mixture of outlooks in order to interest workers in all areas of plant sciences.

\title{
How to reference
}

In order to correctly reference this scholarly work, feel free to copy and paste the following:

Geraldo Magela de Almeida Cançado (2011). The Importance of Genetic Diversity to Manage Abiotic Stress, Abiotic Stress in Plants - Mechanisms and Adaptations, Prof. Arun Shanker (Ed.), ISBN: 978-953-307-394-1, InTech, Available from: http://www.intechopen.com/books/abiotic-stress-in-plants-mechanisms-andadaptations/the-importance-of-genetic-diversity-to-manage-abiotic-stress

\section{INTECH}

open science | open minds

\section{InTech Europe}

University Campus STeP Ri

Slavka Krautzeka 83/A

51000 Rijeka, Croatia

Phone: +385 (51) 770447

Fax: +385 (51) 686166

www.intechopen.com

\section{InTech China}

Unit 405, Office Block, Hotel Equatorial Shanghai

No.65, Yan An Road (West), Shanghai, 200040, China

中国上海市延安西路65号上海国际贵都大饭店办公楼405单元

Phone: +86-21-62489820

Fax: $+86-21-62489821$ 
(C) 2011 The Author(s). Licensee IntechOpen. This chapter is distributed under the terms of the Creative Commons Attribution-NonCommercialShareAlike-3.0 License, which permits use, distribution and reproduction for non-commercial purposes, provided the original is properly cited and derivative works building on this content are distributed under the same license. 